\title{
DO TRABALHO DE CAMPO AO ARQUIVO DIGITAL: PERFORMANCE, INTERACÃOA E TERRA DE ARNHEM, AUSTRÁLLA
}

\author{
Jessica De Largy Healy \\ École des Hautes Études en Sciences Sociales - França \\ University of Melbourne - Austrália
}

\begin{abstract}
Resumo: Dado que o desenvolvimento das tecnologias de informação e de comunicação conhece um esplendor sem precedentes, inúmeros grupos autóctones se apropriam das possibilidades ofertadas pela mídia para projetar no mundo as representações originais de sua identidade de seu patrimônio cultural. Em Galiwin'ku, na Terra de Arnhem australiana, os Yolngu se lançaram numa iniciativa ambiciosa, a de integrar o rom, a lei ancestral, a um projeto de arquivo cultural digital. As questões ligadas à organização e ao acesso do saber sobre $o$ arquivo do Galiwin' $k$ Indigenous Knowledge Centre se articulam em torno dos modos tradicionais de transmissão dos conhecimentos através do gurrutu, a organização social clânica. Esta tensão entre a estrutura digital e a performance ritual permite uma reavaliação da disposição em redes dos saberes locais.
\end{abstract}

Palavras-chave: antropologia, arquivo digital, conhecimento indígena, Yolngu.

Résumé: Alors que le développement des technologies de l'information et de la communication connaît un essor sans précédent, de nombreux groupes autochtones se saisissent des possibilités offertes par ces média pour projeter dans le monde des représentations originales de leur identité et de leur patrimoine culturel. A Galiwin'ku, en Terre d'Arnhem australienne, les Yolngu se sont lancés dans une initiative ambitieuse, celle d'intégrer le rom, la loi ancestrale, à un projet d'archive culturelle numérique. Les questions liées à l'organisation et à l'accès du savoir sur l'archive du Galiwin'ku Indigenous Knowledge Centre $s$ 'articulent autour des modes traditionnels de transmission des connaissances à travers le gurrutu, l'organisation sociale clanique. Cette tension entre la structure numérique et la performance rituelle permet une réévaluation de la mise en réseaux des savoirs locaux.

Mot-clés: anthropologie, archive numérique, connaissance indigène, Yolngu.

Keywords: antropology, digital archive, Indigenous knowledge, Yolngu. 
Após alguns anos, numerosos projetos de multimídia testemunham a utilização original que fazem os povos autóctones desse suporte e das tecnologias de informação em geral (Ginsburg, 1991; Kupiainen, [no prelo]; Nathan, 2000; Smith; Ward, 2000; Taylor, 1991). ${ }^{1}$ Em 2001, o CNRS e a UNESCO organizaram em Paris (França) um simpósio internacional, intitulado Identidades Indígenas: Expressões Escritas e Orais e as Novas Tecnologias, que tratou de temas sobre a manutenção da cultura, a transmissão e a mudança, e os benefícios potenciais das novas tecnologias para os grupos autóctones (Stenou; Vacheron; Glowczewski; Stanton; Rotkowski, no prelo). ${ }^{2}$

A apropriação e a adaptação das tecnologias de informação e a comunicação por diferentes grupos aborígenes na Austrália é um fenômeno descrito em várias publicações recentes (Langton, 2001, Molnar; Meadows, 2001, Nathan, 2000, Smith; Ward, 2000). Segundo Langton (2001), a rapidez desse fenômeno está ligada à necessidade, e às novas possibilidades de comunicar suas próprias preocupações, após dois séculos de representação pelos australianos ocidentais. Langton associa essas estratégias ao domínio mais amplo de "gestão dos recursos culturais", um termo que designa freqüentemente as atividades indígenas de conservação do patrimônio natural. Nesse contexto, tanto pode referir-se aos projetos de transmissão cultural nas escolas quanto em websites de organizações políticas aborígenes (Aboriginal and Torres Strait Islander Commission, Northern Land Council...), de fundações (Yothu Yindi Foundation), de centros artísticos comunitários (Buku-Larrnggay Mulka Centre, em Yirrkala) ou de artistas individuais (Djälu Gurruwiwi, o mestre de yidaki ou didjeridu). Alguns antropólogos souberam captar as oportunidades oferecidas pelas novas tecnologias para restituir seus dados etnográficos para as comunidades aborígenas (Glowczewski, 1999a, 2000, 2001; Gurrmanamana; Hiatt; McKenzie, 2002). A Universidade do Território do Norte (NTU), há pouco transformada em Charles Darwin University, oferece, na Faculdade de Estudos Aborígenes e das Ilhas de Torres, um curso de estudos yolngu em

\footnotetext{
Todos os endereços eletrônicos dos sites citados estão disponíveis em lista, ao final do artigo. 2 Diagram 1. Heidegger's dialectical metaphysicsColóquio co-organizado pela $\mathrm{Dr}^{\mathrm{a}}{ }^{\mathrm{a}}$ Glowczewski (Laboratoire d'Anthropologie Sociale, CNRS) e Dr. Stanton (University of Western Australia) a partir de uma cooperação fraco-australiana, Art et Multimédia, dentro da Década Internacional dos Povos Autóctones do Mundo, da UNESCO.
}

Horizontes Antropológicos, Porto Alegre, ano 10, n. 21, p. 67-95, jan./jun. 2004 
linha, desenvolvido em colaboração com os Yolngu (Christie; Gaykamangu; Nathan, 2001). Assim destinado à transmissão intercultural, o arquivo digital Arra Irititja dos Pitjantjatjara é um dos projetos de maior amplitude no domínio da gestão cultural aborígene. Cada vez mais os diferentes grupos aborígenes exigem receber as cópias dos filmes, as fotos e outros suportes etnográficos produzidos pelos pesquisadores, para constituir arquivos pessoais ou comunitários.

O controle da produção e da distribuição dos recursos culturais é para os povos indígenas um meio de comunicar diretamente entre eles e com os outros em um formato apropriado, e de promover uma identidade autóctone segundo os próprios termos (Glowczewski, 2001). Assim, na Austrália, os numerosos grupos aborígenes apropriaram-se das oportunidades oferecidas pelas novas tecnologias para reivindicar um status de autores sobre as produções culturais e suas estratégias de auto-representações. A propósito da utilização das novas mídias na produção do CD-ROM Yapa: Art Rituel du Désert Central Australien, Barbara Glowczewski explica que:

A navegação seminômade no deserto seguia os itinerários míticos balizados de toponímias. A lógica em rede do sistema cognitivo do deserto oferecia, pois, uma estrutura ideal para navegar de maneira reticular no universo digital. Eu construí uma minirrede desses itinerários e sítios, com a possibilidade de mudar o caminho conforme os laços propostos pelas palavras ou as imagens digitalizáveis, em que os hipertextos oferecem as telas novas que, em vez de encaminhar somente a um parágrafo explicativo - à maneira de notas de um livro -, oferecem a possibilidade de seguir um outro programa: um outro itinerário mítico, um rito filmado correspondente à narrativa, uma pintura ilustrada, uma canção de acompanhamento, etc. (Glowczewski, 1999b, p. 85).

Nathan (2000) justifica o número importante de sites indígenas na Internet pela natureza do instrumento mesmo, um meio que coloca em questão os modos standard de alfabetização. Ele sublinha as possibilidades novas de integrar os valores autóctones em um meio que está sempre em curso de transformação. Entretanto, em uma entrevista de 1997 sobre os websites aborígenes da Austrália que examina a participação aborígene no desenvolvimento do conteúdo, da arquitetura, da programação em HTML e na 
manutenção do site revela que, apesar das raras exceções, é comum os sites ditos "aborígenes" serem publicados sem a participação ativa por parte dos aborígenes, sua contribuição tendo sido freqüentemente limitada ao conteúdo do site (Hobson, 1997).

Em um artigo sobre o problema da "fluidez" no discurso antropológico, e mais particularmente em relação às sociedades aborígenes, Sutton (2001, p. 31) assinala a necessidade de considerar ao mesmo tempo "as continuidades e as descontinuidades que caracterizam os múltiplos atos de produção no tempo" e de distinguir "a produção da reprodução, ou seja, da repetição da forma e do conteúdo em oposição aos eventos singulares ou às séries de diferenciados eventos". O que me interessa aqui é a idéia de continuidade na produção cultural ligada à utilização das novas tecnologias, a maneira pelo qual os aborígenes se apropriam dos instrumentos da informática a fim de desenvolver as estratégias de representações originais. O etnólogo canadense Eric Michaels aporta uma perspectiva interessante a essa noção de continuidade ao qualificar a Austrália aborígene de economia oral de informação, em que "uma vasta rede de difusão entre as associações distintas dividem o continente, transmitindo as informações necessárias à extração de sentido e de utilidade da paisagem. Na Austrália aborígene contemporânea o grande interesse dado ao rádio, ao telefone e outros sistemas de comunicação eletrônica pode, pois, ser considerado como uma continuidade cultural, e não como uma novidade." (Michaels, 1985, p. 509).

No Oeste da Terra de Arnhem, von Sturmer (1984) mostrou que, em prejuízo de um universo social ampliado pela colonização e pela sedentarização, os mecanismos e os processos tradicionais de transmissão, de recepção e de decodificação da informação pouco mudaram.

Alhures, os Warlpiris, do deserto ocidental, foram bem sucedidos em utilizar as tecnologias na constituição de novos objetos culturais; por exemplo, tomando a direção da produção de vídeos para realizar filmes segundo seu modo de organização social (Michaels, 1994, Michaels; Kelly, 1984). O estudo das técnicas de utilização das tecnologias da comunicação pelos aborígenes pode nos ajudar a compreender certas representações que os grupos podem projetar eles mesmos. Em um contexto intercultural se trata tanto da representação que eles têm deles próprios quanto aquelas que eles querem transmitir às novas gerações e aos usuários não aborígenes.

Para que a participação dos aborígenes não seja limitada aos conteúdos dos produtos, mas, antes, que venha a traduzir a maneira autóctone de fazer 
as coisas, é essencial que ela se exerça sobre o conjunto da cadeia de produção: da tecnologia ou método empregado à constituição de um artefato, que permanece propriedade cultural do grupo aborígene em questão. Aqui as noções de "tecnologia" e de "artefato" são entendidas no sentido proposto por Chase (1981), em uma definição mais ampla sobre a cultura enquanto "maneiras de fazer as coisas socialmente e de chegar a objetivos particulares". Segundo essa definição, toda uma variedade de projetos de comunicação pode se tornar artefatos, a expressão de representações culturais, como o filme de MacDougall Familiar Places (de 1980), filmado em Cape Keerweer em 1977 com o antropólogo Peter Sutton (1978).

O conceito de totem, enquanto um emblema identitário do clã, é intimamente ligado à idéia de história ou de narração. Uma referência expressa, ou a demonstração de um objeto totêmico, exorciza ao mesmo tempo a identidade de seu clã e a narração associada. É assim, como assinala Peter Sutton, pouco após as filmagens de um filme talvez conhecido pelos aborígenes como um meio de referência suplementar, pois ele demonstra ritualmente e então dá um reconhecimento aos objetos e lugares. E, em se fazendo, ele adquire todas as conotações ligadas às "histórias" e às narrações. Quando isto acontece, o filme ele mesmo se torna uma nova história e um objeto de importância totêmica. Ele não é percebido unicamente como a história do diretor do filme; ele se torna efetivamente uma propriedade cultural aborígene. (Sutton, 1978, p. 1 apud MacDougall, 1991, p. 8).

O controle sobre o material e a propriedade do produto é um aspecto essencial deste processo de apropriação. Um tal sentido de propriedade é também articulado ao fim do filme de Kim McKenzie, Waiting for Harry (de 1980), logo que o organizador do ritual, Frank Gurrmanamana, anuncia à assembléia dos participantes: "Este filme é também meu filme. Agora as pessoas em todos os lugares vão ver meus emblemas sagrados, justo como, em vários lugares, eu vi os seus. Os emblemas que me são caros ao coração estão agora em um filme, então esse filme eu guardo no coração também." (apud MacDougall, 1991, p.7). Este último ponto traz à tona um número de questões interessantes para meu projeto de pesquisa, mais particularmente sobre a relação entre os indivíduos, os objetos e as imagens midiatizadas 
desses objetos. No caso de um arquivo digital isto terá conseqüências na maneira pela qual as pessoas organizam o saber e criam as associações entre os elementos. Ele é, pois crucial no momento de colaborações sobre os projetos de transmissão cultural, de dar conta das epistemologias locais, pois, como escreve Postman (1985), "cada mídia, como a linguagem ela mesmo, torna possível um modo de discurso único, fornecendo uma nova orientação para o pensamento, à expressão e a sensibilidade" (Postman, 1985, p. 10).

As questões ligadas à epistemologia estão no centro de todo projeto de arquivo cultural, enquanto representações possíveis do saber autóctone. Pois é importante perceber que se um arquivo tem por função representar o saber, ele não lhe conterá enquanto tal (Christie, 2003). Se um arquivo, enquanto artefato cultural, pode representar o saber, e então ter um sentido real para seus usuários, a transmissão do saber permanece intimamente ligada à performance. Por exemplo, é tanto pelos processos das dinâmicas cerimoniais quanto nas reuniões e acampamentos familiares que o yolngu é atualizado, reafirmado e transmitido. São as articulações entre a estrutura digital do saber e a performance de cerimônias que eu descreverei na segunda parte deste artigo.

\section{A Terra de Arnhem: contexto social e histórico}

A Terra de Arnhem é um truste ${ }^{3}$ de $97 \mathrm{mil} \mathrm{km}^{2}$, estabelecido em 1931, no Nordeste tropical do Território do Norte australiano. Os 11 mil aborígenes que ali vivem, os Yolngu, ${ }^{4}$ detêm os direitos fundiários hereditários sobre os diferentes territórios que compõem a reserva. Cada território é identificado e pertence a pequenos grupos patrilineares exogâmicos (bapurru) que são afiliados a um ou outro patrimoniado yolngu: dhuwa e yirritja. Tudo o que existe é repartido entre dhuwa e yirritja, os homens, as plantas, os animais, os fenômenos naturais, os objetos, os ancestrais criadores, etc. "Cada artigo", escreve Warner (1937, p. 31), "encontra seu lugar em um sistema ideológico elaborado que é expresso no mito e no folclore". Estruturalmente os Yolngu classificam seus dialetos em sete yolngu-matha "línguas". Esses

\footnotetext{
3 No original francês Trust foncier (N. de T.).

4 Significa "pessoa" (N. de T.).
} 
matha pertencem ao grupo lingüístico aglutinando pama-nyungan e são classificados segundo a palavra, querendo dizer "isto/aqui", como, por exemplo, os grupos lingüísticos dhuwal e dhuwala. Cada clã, ou patronímico, ${ }^{5}$ bapurru, se identifica com uma língua particular que lhe foi legada por um ancestral criador, wangarr, durante o tempo da criação.

Os territórios com seus recursos naturais e religiosos, madayin (o sacro) (Keen, 1994; Thomson, 1949; Warner, 1937), foram criados e herdados dos ancestrais wangarr, estes seres criadores dos quais os Yolngu dizem descender. Os diferentes territórios e seus proprietários são conectados entre si pelos laços rituais instaurados durantes as viagens dos ancestrais wangarr. A divisão de certos recursos religiosos, assim como as relações de parentesco entre os territórios, é a manifestação de laços mitológicos inscritos na terra que conferem a cada clã um número de direitos e de responsabilidades em relação aos territórios de outros grupos. Essas redes de obrigação e de interesse, que estão na base da organização social Yolngu (gurruțu), encontram uma aplicação em todos os domínios. As obrigações e as contra-obrigações, definidas pelo pertencimento clânico, e o gurrutu, são notadamente a motivação para a produção de bens (Thomson, 1949). Assim, cada coisa nomeada é ligada a um clã particular e por associação a outros clãs da mesma metade; os clãs assim conectados são denominados ringgitj.

Os primeiros visitantes da Terra de Arnhem foram os pescadores macassans, vindos do porto de Macassar, com quem os Yolngu mantêm intercâmbio de relações comerciais desde o início do século XX. Os macassans introduzem os novos bens na estrutura econômica yolngu. Os objetos novos, tais como o metal ou o tabaco, são celebrados em certas séries de manikay, suas performances de cantos e de danças rituais, herdadas dos tempos dos wangarr (Macknight, 1972; McIntosh, 1996; Toner, 2000; Warner, 1937). A influência macassan se encontra também no vocabulário de numerosos clãs costeiros yolngu: palavras tais como balanda (do indonesiano, por Hollander) ou rrupiya são dos nomes dos lugares, mas também dos prenomes que continuam a ser transmitido entre os clãs hoje em dia (Warner, 1937, p. 464).

\footnotetext{
${ }^{5}$ No original francês patrilecte (N. de T.).
} 
Jessica De Largy Healy

O contato com os europeus foi bem mais tardio na Terra de Arnhem que nas regiões mais férteis e acessíveis do Sudoeste do continente. Foi somente em 1920 que as missões religiosas estabeleceram as primeiras estações de residência permanente na Terra de Arnhem. A sedentarização dos Yolngu foi acelerada nos anos 1940, durante a Segunda Guerra Mundial. Existem hoje na região seis comunidades principais yolngu e, depois do movimento de reapropriação das terras nos anos 1970, uma multiplicidade de outstations, esses pequenos acampamentos de famílias situadas nas terras clânicas. Galiwin'ku foi estabelecida de modo permanente em 1942 pelo reverendo Sheppherdson, missionário metodista, e funciona no presente como uma municipalidade gerenciada por um conselho de eleitos representando os clãs ali residentes.

Desde os anos 1930, existem numerosos dados etnográficos sobre os Yolngu. A Terra de Arnhem representa um espaço privilegiado da tradição antropológica aborígene. Donald Thomson, Lloyd Warner e os Berndt têm as primeiras coleções dos objetos yolngu que são atualmente conservados nos museus. A venda de objetos de arte inicialmente promovida pelos missionários constitui ainda uma das fontes econômicas principais para as comunidades yolngu. Em face de uma cultura que continua a "sair", a vontade de constituir o centro dos saberes de Galiwin'ku se articula em torno de dois pontos: o acesso aos materiais contidos nos museus por meio do repatriamento digital e o registro de informações para manter a cultura no seio da comunidade.

O projeto do centro dos saberes de Galiwin'ku se inscreve na continuidade de uma série de manifestações públicas yolngu iniciadas depois do fim dos anos 1950. Em 1958, o adjustment mouvement descrito por Berndt (1962) colocava em evidência as tentativas dos líderes yolngu de fazer reconhecer a importância da cultura tradicional das autoridades da época, os missionários e a administração do governo australiano, com o objetivo de reivindicar o controle sobre as mudanças sociais e culturais que afetavam suas comunidades. Berndt interpreta este movimento como a "manipulação prática" de uma situação em que os Yolngu escolhem a riqueza de sua cultura que eles querem transmitir aos europeus no âmbito de um mercado: a demonstração pública dos emblemas sagrados dos clãs ranggas, em troca de uma maior autonomia, sobretudo no domínio econômico. Tais manifestações tomam hoje novas formas, como a organização anual do festival de 
Garma em Terra de Arnhem, onde são convidados os universitários, os políticos e os membros do público em geral para descobrir a cultura yolngu. Garma é hoje um dos principais fóruns de troca e de discussão entre os Yolngu e os balandas e, nesse sentido, não é surpreendente que por ocasião do último festival, em agosto 2003, duas sessões dos simpósios que se desenvolvem paralelamente às atividades culturais eram consagradas aos projetos de centros dos saberes.

\section{0 projeto do centro dos saberes de Galiwin'}

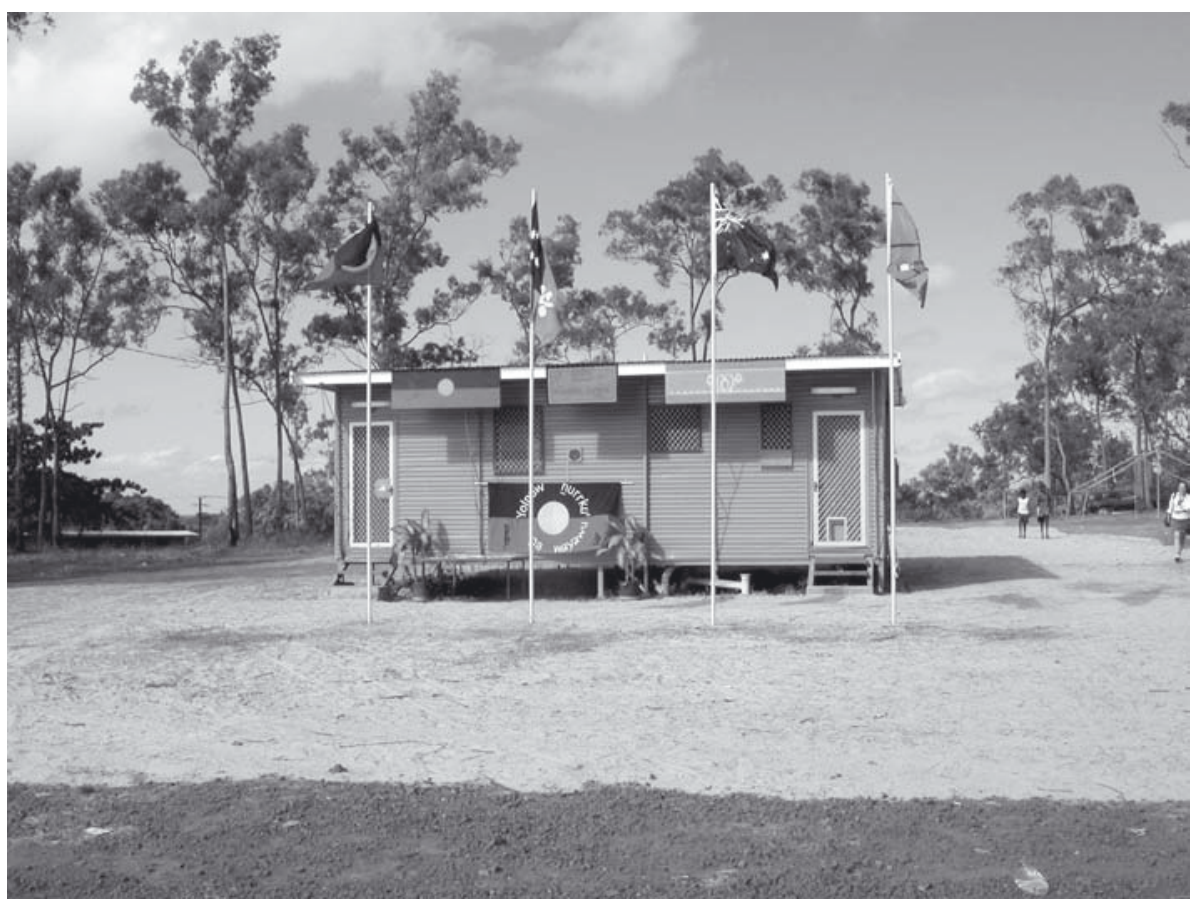

Foto 1. Centro dos saberes de Galiwin'ku, 2003

Depois de alguns anos os departamentos governamentais australianos desenvolvem uma política ativa de desenvolvimento das tecnologias de informação e da comunicação nas regiões isoladas do continente. No nível local, os computadores e os utensílios informatizados em geral, aí compreendidas 
as conexões à Internet, se multiplicaram nos diferentes departamentos municipais yolngu, no centro de educação e de formação para adultos, as escolas, as prefeituras. Logo depois, outras organizações comunitárias começaram a se interessar pelas possibilidades ofertadas pelas novas mídias.

O projeto do Galiwin'ku Indigenous Knowledge Centre ou centro dos saberes de Galiwin'ku, nasceu nos anos 1970, no village council, nas reuniões comunitárias de líderes yolngu que, dos tempos das missões, tinham por objetivo discutir a política interna à ilha, assim como as mudanças vindas do continente. A idéia, ou a "visão", segundo os diretores yolngu do centro, teria surgido do desejo de estabelecer um vínculo de conservação da cultura, em vista de uma situação onde a troca tinha sido percebida como sendo de um único sentido: que nessa troca, seja de produção artística ou de informações culturais, segundo os líderes yolngu, a cultura não fazia nada mais do que "sair". Em 2002, graças a uma subvenção atribuída pelo governo do Território do Norte, o centro dos saberes de Galiwin'ku começava suas operações a partir de um pré-fabricado localizado no centro da cidade, em frente ao conselho municipal. A subvenção do Departamento das Bibliotecas e dos Serviços da Informação (NTLIS) deveria ser utilizada para desenvolver uma rede regional de centros dos saberes, e o de Galiwin'ku era o primeiro e o hub central da futura rede. O comitê de direção do centro é composto de representantes de alguns dos 20 clãs que coabitam na ilha, onde encontramos quatro serviços assalariados que são os postos de Diretor, Manager, Responsável pelas Relações com a Comunidade e de Responsável das Relações Exteriores e da Formação.

Os objetivos do centro dos saberes incluem a preservação, a transmissão e o repatriamento da cultura através de um arquivo digital em linha que conterá as informações culturais yolngu - entre as quais aquelas conservadas nas diversas coleções etnográficas - a fim de torná-las acessíveis à comunidade. Trata-se também de fazer do centro um espaço de aprendizagens e educação onde os aborígenes e os balandas poderão seguir um ensino yolngu em uma estrutura e sob a direção dos líderes yolngu. Este último ponto diz respeito particularmente aos pesquisadores, na medida em que numerosas comunidades aborígenes exigem atualmente acordos contratuais detalhados antes de atribuírem as permissões de pesquisa. A retomada do ensino de sua cultura é um tema recorrente no discurso yolngu. Assim, eles entendem o centro dos saberes como uma passagem obrigatória para a aprendizagem. Concretamente, isso se traduz por um desejo de es- 
tabelecer as colaborações com os universitários, os institutos de pesquisa, como o Instituto Australiano dos Estudos Aborígenes e das Ilhas de Torres (AIATSIS) e os museus.

O centro dos saberes de Galiwin'ku se apresenta, pois, antes de tudo, como um lugar de aprendizagem e de transmissão dos conhecimentos. Em seu discurso de inauguração do centro dos saberes, Matthew Baltha Ngulupam Gaykamangu, o manager do centro, explica que:

O centro dos saberes vai ser a via do futuro para o trabalho sobre a cultura e a lei. É sobre a terra, o mar, a língua das pessoas, a língua yolngu. É uma boa coisa para nossa comunidade aqui. Se o centro dos saberes fracassasse isso afetaria as novas gerações. Porque a geração dos jovens que deixaram a escola é agora adulta, o centro dos saberes vai continuar a transmitir as histórias. Eles conservarão as histórias culturais até que eles se tornem velhos: os ringgitj, a dança, a lei, a lei cultural e a identidade dos Yolngu, a vida das pessoas. (Gaykamangu, 2003).

A geração de que fala Baltha é a dos jovens adultos (15-25 anos) que abandonaram a escola e que vadiam, que não possuem as "fundações", uma noção sobre a qual eu retornarei. Os antigos se inquietam que eles não estejam nem em sintonia com sua própria cultura, nem com aquela imposta pela Austrália ocidental. O projeto constitui a este título um lugar de ensino alternativo que, como reparou Bárbara Glowczewski (1999b) a propósito de outros projetos de transmissão autóctones contemporâneos, procura integrar os conhecimentos intelectuais locais a um modo de aprendizagem ocidental.

Esta pesquisa, que consiste na minha tese de doutorado, é centrada sobre as formas que os Yolngu escolhem para incorporar as novas tecnologias em sua tradição cultural, e em particular como eles negociam, manipulam e se apropriam do controle de uma infra-estrutura digital a fim de criar, a partir dessa mídia, um objeto significante. No contexto de meu acordo de pesquisa, eu me engajei em oferecer ao centro um certo número de horas de trabalho voluntário, principalmente a responsabilidade de testar o sistema informatizado e de desenvolver, em consulta com os Yolngu, as estratégias e as soluções aos numerosos desafios que a organização da estrutura do arquivo colocava. Baseada em uma pesquisa de campo 
Jessica De Largy Healy

etnográfica inicial de seis meses, eu compreendi plenamente a medida do projeto do centro dos saberes de Galiwin'ku. O arquivo digital não é em nenhum caso um fim nele mesmo, os percursos de uma cultura Yolngu formatada, ao contrário, como explica Joe Neparrnga Gumbula, um outro diretor do centro dos saberes:

Nós não queremos recuperar este material porque a cultura desapareceu, ao contrário, ela está sempre presente, em nós. Nós não queremos simplesmente somar qualquer coisa a mais a isto, do que fazemos agora por esta geração. E é o tipo de coisa que nós queremos colocar em pauta [nos arquivos digitais], para lhes desenvolver ainda mais no nosso saber contemporâneo. Ver nossa cultura mais divulgada... Acrescentar coisas mais preciosas. Acrescentar coisas à pesquisa, estudar mais, acrescentar os potenciais. (Gumbula, 2003a).

Os Yolngu, como os Warlpiri, são conscientes de que o conteúdo do arquivo "não é exaustivo de sua cultura, mas somente um modo de acumular e reunir" (Glowczewski, 1999b, p. 95). A restituição digital de objetos conservados nas coleções de museus tem o potencial de restaurar uma comunicação com os Yolngu e seus objetos sagrados. Os Yolngu pensam, com efeito, que a interação mediatizada com seus objetos e outras representações culturais, como os velhos registros e as fotos históricas, permite a reincorporação destes na cultura viva, através da performance de bunggul (cerimônias incluem os cantos, as danças e a pintura de motivos rituais). Pois o saber é antes de tudo uma performance que não pode ser atualizada se não através da participação humana.

\section{Representar a organizacão do saber Yolngu: a estrutura do centro dos saberes de Galiwin'ku}

Os benefícios oferecidos pelos instrumentos da informática, compreendendo nesse contexto a necessidade de aprendermos como utilizá-los, são reconhecidos pelos líderes yolngu, que compreendem que ao mesmo tempo podem fazer proveito para aceder aos objetos distantes, manter a cultura e projetar suas próprias representações no mundo. 
Considerando-se que os bancos de dados, enquanto instrumentos de gestão de informação, influenciam nossa maneira de perceber o ambiente, torna-se essencial para tal projeto de poder estruturar a informação segundo os princípios de organização autóctones. A maneira pela qual os Yolngu classificam a informação, imaginam as conexões e criam as categorias são as questões que se situam no coração da constituição do arquivo digital, como vamos mostrar doravante.

Depois que o servidor e a rede de computadores foram instalados no centro dos saberes de Galiwin'ku, em março de 2003, grande parte do trabalho foi o de testar o protótipo desenvolvido por uma sociedade privada de programadores de Darwin, a fim de verificar sua facilidade de utilização pelos Yolngu, e de revelar as críticas e as idéias dos utilizadores a fim de melhorar o funcionamento e a arquitetura. Essa atividade se revela complexa na medida em que o nível geral de competências informatizadas permanece ínfimo na comunidade. São os adultos, que em média estão com 40 anos de idade, que melhor dominam os computadores e que foram por isso convidados para trabalhar no centro sob a supervisão dos quatro diretores. Cabe aqui assinalar que nessas condições o comitê de direção tem uma idéia clara da maneira pela qual o sistema deveria operar: as estruturas de classificação e de acesso à informação devem refletir uma organização do saber e uma lógica yolngu.

Uma base de dados não é uma estrutura neutra: como todo sistema de classificação, ela influencia nossa maneira de perceber o mundo. Bowker (2000), por exemplo, descreve esse fenômeno no domínio da pesquisa em biodiversidade. A base de dados cria o mundo à sua imagem, escreve $\mathrm{o}$ autor, e ela pode nesse sentido ser qualificada de infra-estrutura performativa. Ela serve de instrumento de gestão ao imperialismo, um fenômeno que se traduz hoje pelo fluxo de dados oriundos do Terceiro Mundo em direção aos bancos de dados ocidentais, onde eles são convertidos em informação e em saber comercializáveis, e depois revendidos. Os projetos autóctones do centro dos saberes são uma das respostas locais a essa situação.

Se a classificação, isto é, a maneira pela qual as pessoas classificam e religam os objetos e os fenômenos de seu ambiente, reflete uma compulsão humana pela ordem (Lévi-Strauss, 1962, p. 30), Lévi-Strauss escreve também que "La vérité est que le principe d'une classification ne 
se postule jamais: seule l'enquête ethnographique, c'est-à-dire l'expérience, peut le dégager a posteriori." (Lévi-Strauss, 1962, p. 77). Também Glick (1964) insiste sobre o fato de que uma metodologia inadequada não faria nada mais que expressar uma espécie aleatória de crenças exóticas. Segundo esse autor, o etnógrafo deve colocar de lado suas próprias concepções sobre as categorias e suas relações e tentar compreender os princípios, os procedimentos e as regras que são operacionais na cultura que ele ou ela estudam (Glick, 1964, p. 273). Glick define "categoria" enquanto agrupamento reconhecido no sistema de classificação autóctone. Esclarece o autor que a delimitação dessas categorias e a aprendizagem de que elas incluem ou não, assegura que todo estudo ou descrição emitida será organizado de acordo com os cânones classificatórios autóctones (Glick, 1964, p. 273).

No caso do centro dos saberes de Galiwin'ku, a organização e a apresentação da informação sobre o sistema são um dos recordistas dos objetivos maiores da construção do banco de dados. A taxonomia linear e outros modelos classificatórios inspirados nas ciências naturais não refletem, de maneira adequada, a forma como os Yolngu organizam a informação ou imaginam as conexões e compreendem suas categorias. Para ilustrar a complexidade das questões de classificação, considera-se um caso que se apresenta no centro dos saberes, aquele da categoria warrakan. Warrakan é a palavra que em yolngu-matha designa uma categoria de animais que engloba os mamíferos terrestres e aquáticos, os répteis (com exceção das serpentes) e os pássaros (Rudder, 1998). No menu principal do arquivo, o termo foi traduzido para o inglês como "animals". Essa tradução é problemática, pois os usuários yolngu não pensariam em procurar, a partir dessa categoria, os peixes, por exemplo. De qualquer forma, para os Yolngu não é lógico distinguir nessa precisão as categorias como plantas, animais, moradias, cantos e bunggul. Que uma coisa seja uma planta ou um animal não determina sua classificação em uma mesma categoria. Os campos devem ser criativos e mutáveis para integrar as relações que eles entretêm no seio de um sistema de saberes que é estruturado pela propriedade da terra e do parentesco. Por exemplo, quando interrogados sobre um grupo de animais que figuram juntos na pintura feita sobre uma casca de árvore, Joe Neparrnga Gumbula, um dos diretores do centro, explica que eles são todos representados, dado que: 
Eles pertencem à mesma cratera d'água. E este buraco d'água é de fato ligado a este larrakitj [recipiente funerário], este djalumbu [recipiente funerário]. E este é um motivo Gupapuyngu unicamente. Estas pessoas têm seus próprios motivos, suas próprias crenças, suas próprias histórias. Cada clã tem seus cantos e suas danças únicas. (Gumbula, 2003b).

Para que o arquivo se constitua num objeto que represente o gurruthu, a organização social clânica, ele deve se situar na base de sua arquitetura. A entrada na hierarquia do clã deve ultrapassar as categorias existentes, orientando a navegação e criando uma rede diferenciada de conexões para cada usuário, isto também se aplica para o caso deste sesituar no âmbito do dominio publico da informação, ou garma. Isto se torna mais evidente no momento em que se considera um outro testemunho de Joe Neparrnga Gumbula, onde ele explica a ambigüidade do termo dharpa, "planta".

Uma dharpa [planta] são todas as dharpa, as árvores são as dharpa. Mas de que dharpa exatamente trata-se de descrever? Digamos, por exemplo, que tomemos uma dharpa eucalyptus, OK? É uma dharpa, um eucalyptus. Mas a quem pertence o eucalyptus? Então [mostrando um eucalyptus pela janela] esta dharpa aqui é da metade dhuwa. E de lá, da metade dhuwa, pode-se contar quantas, talvez, uma vintena [de clãs]. Em seguida dir-se-á "conforme, dhuwa Djambarrpuyngu [nome de clã dhuwa]". Certo, mas quais cantos Djambarrpuyngu ? Qual é sua cabeça de manikay? Como são os movimentos de eucalyptus Djambarrpuyngu? Como são os movimentos do eucalyptus Rriratjingu [nome do clã dhuwa]? Etc., etc., etc. E em seguida eles terão um canto desta dharpa particular. E eles terão qual o pássaro que pousa sobre a extremidade da dharpa no itinerário do canto Djambarrpuyngu. Qual a abelha produtora de mel ali pousa. E daí aprender-se-á quem está implicada, quem é meu märi (MM), quem vem em minha direção ou eu vou a direção ao märi. E isto continua... (Gumbula, 2003b).

A fim de constituir um objeto culturalmente significante, o arquivo digital - isto é, a organização de estocagem, de acesso e de manipulação das 
informações - deve ser estruturada pelo sistema de restrições, prevalecendo em outros domínios de saber. Assim, pode-se considerar o arquivo digital como "sistema de ordem" com as implicações similares àquelas notadas por Morphy em relação à produção artística yolngu: os princípios de organização do conteúdo do saber e das relações entre os diferentes níveis de saber são de importância igual ao conteúdo do saber (Morphy, 1991, p. 77). Em outros termos, para constituir um objeto significante, a boa representação do saber através da arquitetura de arquivo é tão importante quanto as informações culturais contidas na base de dados. A representação do saber yolngu é, pois, dependente da interação em rede dos saberes locais ou clânicos, uma estrela ancestral que é inscrita na terra e que se manifesta através da performance de cerimônias. Esses princípios de agenciamento são descritos em uma pintura realizada por um dos diretores do centro, para demonstrar ao público as fundações teóricas do centro. O quadro pintado por Joe Neparrnga Gumbula (Foto 2) pode ser lido como uma matriz para várias entradas, refletindo as diferentes articulações que existem entre o saber e o gurrutu.

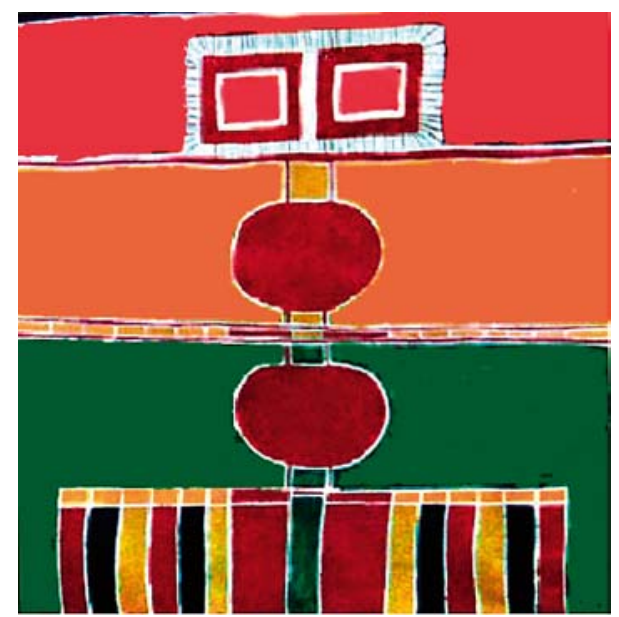

Foto 2. Estrutura do centro dos saberes de Galiwin'ku, de Joe Neparrnga Gumbula, 2003 


\section{Os domínios do saber yolngu}

O quadro mostra três domínios de saberes colocados em evidência na pintura por um código de cores: verde, garma, domínio público; laranja, dhuni, domínio sagrado, acessível aos indivíduos iniciados; vermelho, ngärra, domínio secreto e sagrado altamente restrito, acessível unicamente aos homens iniciados no mais alto nível e a certas velhas mulheres. $\mathrm{Na}$ pintura como na realidade esses três domínios de saberes são interligados por uma linha que junta, de uma parte, os três terrenos de performance rituais - os círculos - e, de outra parte, as duas metades exogâmicas yolngu, dhuwa e yirritja. A interdependência dos três domínios de saberes é sublinhada por Morphy (1991), que distingue entre as formas "interiores" e "exteriores" do saber enquanto estrutura conceitual. O saber interior, sagrado, se manifesta no saber exterior, público, que é ele mesmo gerado pelo saber interior. Os conceitos de interior e de exterior, escreve Morphy (1991, p. 83), são também utilizados como princípios para organizar o saber, de maneira a revelar e por vezes criar as relações estruturadas significantes entre as coisas.

Garma, a palavra garma exprime o reencontro das pessoas para celebrar, para compartilhar o saber garma. E normalmente é organizado por ocasião do falecimento de uma pessoa importante. É uma cerimônia organizada com o objetivo de celebrar. Garma ultrapassa o enterramento do morto. Permite também aos participantes da cerimônia fúnebre apreender o saber, e comunicar o saber que se estende a outras coisas. (Transcrição de discurso, Garma 2001).

Um indivíduo tem a possibilidade de passar pelos domínios garma, dhuni e ngärra no decorrer de sua vida, isso dependendo de um certo número de fatores, incluindo a idade, o sexo e a experiência, e os diretores desejam respeitar as dinâmicas sociais para determinar os níveis de acesso apropriados sobre o arquivo digital. Como por ocasião dos rituais yolngu, a passagem de um domínio a outro deve permanecer estritamente regrada no sistema de informática. Este deve ser suficientemente flexível para dar conta das mudanças no status social do usuário, a fim de que seu perfil possa ser ressituado.

\section{Os princípios sociais de classificação do saber}

Uma outra leitura do quadro de Neparrnga Gumbula ilustra o modelo de organização social yolngu: trata-se de pequenos segmentos que aparecem 
de um lado e de outro da linha central. Gurrutu-watangu designa as maneiras pelas quais os clãs são conectados entre eles pelas relações de parentes imutáveis. Aí aparecem os próprios clãs (rom-watangu), o clã da mãe (ngändi wațangu), clã da mãe da mãe (märi wațangu), clã criança ou mãe da mãe da mãe (waku wațangu), clã irmã (yapa wațangu), clã mãe do pai (momu wațangu) e clã da sogra (milmarra wațangu). Cada uma dessas relações assinala os direitos e as responsabilidades entre os clãs. Por exemplo, a relação yothu-yindi (mãe-criança) é um dos pivôs da organização social yolngu. Essa relação designa dois tipos de grupos: ela engloba os direitos e as responsabilidades de um indivíduo em relação ao clã de sua própria mãe e os direitos e obrigações de um indivíduo em relação a uma série de clãs que são ligados ao clã de sua mãe através do mito e da cerimônia. Essas obrigações incluem a responsabilidade de ser os "trabalhadores" djunggaya, por ocasião da organização de rituais do clã da mãe, destacadamente aquele de produzir as pinturas cerimoniais (Morphy, 1991). Os indivíduos que compartilham do mesmo clã mãe formam um grupo que ultrapassa a organização clânica de sua própria metade. No nível do arquivo digital, essas redes de interesses são o melhor transposto se se estabelece o nível de entrada na hierarquia do clã.

Após algumas consultas com os diretores do centro e os usuários yolngu que testaram o protótipo do banco de dados, uma das proposições seria a de aceder à informação em três níveis: 1) as metades dhuwa e yirritja; 2) gurruțu; 3) a terra. Pois cada clã detém os cantos, as danças, os motivos únicos, centrados sobre as ações particulares dos ancestrais criadores inscritos em sua terra. Se diversos clãs yirritja, por exemplo, cantam ngerrk, a kakatou branca (espécie de papagaio), eles possuem, cada um, um segmento do itinerário mítico do pássaro, relatando seu reencontro com outros protagonistas míticos ou suas ações em um lugar específico. O termo ringgitj designa o conjunto destes clãs da mesma metade que são ritualmente aliados, pois eles descendem dos ancestrais wangarr comuns. Essa forma de aliança se manifesta por ocasião das cerimônias durante a performance de ciclos de cantos manikay e de danças correspondentes, cada clã executando sua própria versão de um evento mítico. A seleção dos temas celebrados e o encadeamento dos cantos seguem um programa estabelecido pelos líderes dos clãs participantes em função de uma reunião ritual circunstancial.

Os repertórios dos cantos yolngu seguem princípios da organização social, eles ora são dhuwa, ora são yirritja, e se transmitem de maneira patrilinear. Os cantos do domínio público são chamados manikay, e são estruturados em três níveis. O nível mais inclusivo é aquele da série ou ciclo, um grupo de cantos associados a um complexo cosmológico único com- 
partilhado pelos clãs ringgitj (Berndt, 1948, 1966). Freqüentemente esses cantos se referem a um lugar específico onde um ancestral wangarr acampou. Cada ciclo é composto de uma dúzia de sujeitos/temas que representam os animais, as plantas, e outras coisas reencontradas pelo ancestral wangarr durante suas viagens. Esses temas podem ser cantos com diversas versões ritmicamente distintas. Cada uma coloca em destaque um aspecto particular das atividades do ancestral wangarr, como a coragem, a cólera, etc. (Toner, 2000, p. 25). Os clãs ringgitj têm em comum certos ciclos de cantos; e dizem que eles entoam "o mesmo canto", mas eles possuem de fato unicamente uma parte dos temas em comum (Keen, 1994, p. 147). Como pelos motivos pintados, a constelação dos cantos é única a cada clã, e é por ocasião das performances que esses saberes são colocados em comum para significar e atualizar tal ou tal aspecto da criação.

\section{Estrutura, interacão e performance da cultura}

A fim de ilustrar a correspondência entre a estrutura do saber e a performance da cultura, Neparrnga Gumbula realizou um segundo quadro, representando uma série de pinturas corporais (Foto 3).

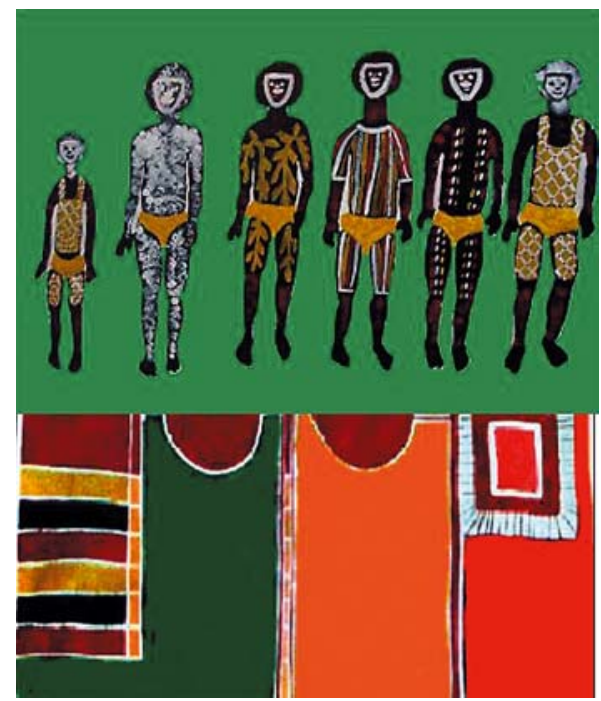

Foto 3. Composiç̃o com desenhos de pintura corporal Gupapuyngu-Daygurrgurr, de Joe Neparrnga Gumbula, 2003 
Este segundo quadro complementa aquele da estrutura do centro dos saberes, precedentemente descrito. Ele representa a progressão de um homem do clã Gupapuyngu-Daygurrgurr (metade yirritja) através do ciclo ritual: da iniciação (garma) ao fechamento das cerimônias funerárias (ngärra). A pintura se superpõe aos três terrenos cerimoniais representados sobre a estrutura do centro dos saberes. A encarnação do ciclo ritual pelos membros dos clãs permite a interdependência e a ativação dos domínios do saber yolngu. É unicamente pela ação humana que a estrutura faz sentido. É por ocasião dos bunggul que o arranjo em comum dos saberes permite a atualização da estrutura em sua forma.

Após seis meses de trabalho de campo em Galiwin'ku, eu fui oficialmente convidada por três dos diretores do centro dos saberes para uma cerimônia dos funerais, que ocorreu em Milingimbi, uma comunidade yolngu em uma ilha vizinha. Eu me encontrava em uma relação yothu/yindi com o defunto, meu ngapipi, ou tio materno classificatório, um homem yirritja, do clã Gupapuyngu Daygurrgurr. Minha presença foi solicitada para melhor compreender as questões gurruțu em uma situação concreta, pela observação das performances dos clãs participantes. A cerimônia reúne os clãs Yirritja Gupapuyngu Daygurrgurr, Gupapuyngu Birrkili, Gumatj, Warramirri e seus "trabalhadores" dhuwa Djambarpuyngu, Dätiwuy, Galpu, Ngaymil et Liyagawumirr. Os funerais tinham por objeto render homenagem ao defunto, o primogênito de Djäwa Dhawirngu Gaykamangu, um líder reconhecido por ter pacificado os clãs yolngu da missão de Milingimbi, reafirmando as alianças rituais entre os clãs participantes.

Joe Neparrnga Gumbula, irmão do defunto e diretor do centro dos saberes, escolhe essa ocasião para declarar publicamente seguir os passos de seu pai e solicita o apoio dos líderes presentes. Ele considera ser seu papel dar continuidade à tradição iniciada por Djäwa Dhawirrngu Gaykamangu colaborando com as instituições para facilitar a restituição das informações culturais aos Yolngu, a fim de que eles retomem o controle sobre a representação de sua cultura. Esta demanda adquire sentido quando se considera que a palavra footsteps, utilizada por Neparrnga Gumbula, é a tradução inglesa da palavra luku, que significa ao mesmo tempo "marca" e "fundação". Se posicionando próximo às cinzas de um fogo de campo superposto depois de várias gerações, a demanda de Neparrnga Gumbula servia para reivindicar suas fundações e se inscrever concretamente em 
uma continuidade genealógica no seio de uma rede de alianças ancestrais. Os princípios do rom, da lei e de sua aplicação, são os mesmos, os Yolngu seguem a mesma estrutura, o mesmo wayawu, ou via. Da mesma forma Neparrnga Gumbula elege esse evento para apresentar aos clãs reunidos as fotos dos anos 1940 da coleção Donald Thomson, reencontradas nos arquivos do Museu de Victoria e nas coleções privadas restituídas pelos antigos missionários. Ele oferece à família do defunto uma foto histórica de seu pai, Djäwa Dhawirrngu, e da mãe do defunto; estas foram penduradas no cômodo em que se encontrava o caixão. É essa participação dos homens e dos objetos na performance, me explica Neparrnga Gumbula, que figura na pintura do centro dos saberes. A integração das fotos antigas na cerimônia contemporânea manifesta a seu turno uma expressão original da dinâmica cultural yolngu. As fotos teriam o potencial de reintroduzir os motivos, os cantos e as seqüências no bunggul. Isso não consiste em "reinventar" os elementos culturais esquecidos, mas, antes, reatualizar certos segmentos da performance que teriam sido abandonadas por uma razão ou outra (De Largy Healy; Gumbula, 2003).

O antropólogo Ian Keen, discutindo essas crenças yolngu, escreve que

Essas crenças implicavam que o traço de uma pessoa ou de um ser (objeto, pintura, foto, sombra) e um fragmento de uma pessoa ou de um ser (cabelo, urina, defecação, suor, unhas) estavam casualmente conectados à pessoa de uma tal maneira que a ação sobre o traço, a imagem ou o fragmento a afetaria. (Keen, 1994, p. 135).

Essa análise tem implicações interessantes para o projeto do centro dos saberes, referentes à ação humana sobre as velhas fotos tiradas por Thomson nos anos 1940 e sobre os objetos contidos nas coleções dos museus. Pode-se perguntar, por exemplo, se a conexão causal descrita por Keen sobreviveu ao tempo e a distância.

Segundo meus informantes yolngu, a resposta é afirmativa, e graças à restituição digital tornada possível pelas novas tecnologias esses objetos podem ser reincorporados na performance. $\mathrm{O}$ reencontro entre o indivíduo e a informação digital, a imagem ou o som midiático, dá lugar a uma interação criadora de sentido. Esses objetos - pinturas, artefatos, registros em áudio e vídeo - jazem "dormindo" nos arquivos dos museus, pois eles 
estão afastados de sua terra e extraídos de sua performance. Em relação à pintura, foi mostrado que "se os componentes existem independentemente da cerimônia enquanto fundamentos da existência dos clãs, eles devem ser performatizados por seres conhecidos. Em outros termos, eles devem ser utilizados nas cerimônias.”(Morphy, 1991, p. 101).

O fato de ver sua imagem projetada em uma tela ou, no caso dos registros sonoros, de poder escutarem-se nas fitas e discos gravados, permite restabelecer uma forma de comunicação com os Yolngu. Os objetos lhes "falam", dizem eles, e eles podem então sonhar os motivos que os recobrem, e podem recomeçar a pintar estas imagens sobre os corpos e a cantar seus nomes sagrados durante os rituais. Keen (1994, p. 135) observa a esse respeito que, "os Yolngu consideram que a performance dos cantos e de danças, a pintura de motivos e a criação de objetos não são somente de ordem da representação ou do simbólico, mas potencialmente eficaz", de maneira que reengajar os objetos na performance lhes devolve de fato seu maarr, ou poder. $\mathrm{O}$ maarr dos motivos pintados é o mesmo que aquele que emana dos objetos sagrados do clã, e que pode ser criado pela invocação dos nomes sagrados cantados pelos líderes rituais (Morphy, 1991, p. 102). Os indivíduos que dividem entre si o maarr dos objetos clãnicos se encontram então afetados por essa reinjeção de poder nos objetos: eles se tornam "fortes" pois eles consolidam suas fundações.

$\mathrm{Na}$ Austrália, várias instituições buscam estabelecer tais formas de colaboração com as comunidades aborígenes. O acesso a certos materiais aborígenes é extremamente regrado: no Instituto Australiano de Etudos Aborígenes e das Ilhas de Torres (AIATSIS) ou no Screensound Australia, no acervo filmográfico nacional, é preciso obter a permissão das autoridades aborígenes para poder consultar certas fontes, como os velhos filmes ou os trabalhos julgados sensíveis. A participação dos aborígenes nos projetos museográficos é também muito solicitada por seu value-adding, o valor acrescentado às coleções permitidas pelo aporte de informações culturais autóctones sobre os diferentes objetos. Assim, o Museu de Victoria, que contém a coleção etnográfica de Donald Thomson, está no momento constituindo um banco de dados dessa coleção: isso abrange certas fotos em preto-e-branco da Terra de Arnhem e de numerosos objetos recolhidos durante seu trabalho de campo, nos anos 1940. O projeto implica um programa de consulta extensiva com diversas comunidades yolngu para identi- 
ficar os indivíduos representados nas antigas fotos e recolher novas informações, que virão somar-se às notas de Thomson. Para os Yolngu trata-se de acessar essas coleções para poder retomar o controle sobre suas representações. Segundo Neparrnga Gumbula

a idéia de recuperar o material sob uma forma digital em um banco de dados é a razão pela qual nós estabelecemos as parcerias com estas pessoas e estas instituições, pois é tempo de fazê-lo nós mesmos, de fazer nós mesmos com o apoio das pessoas que arquivam estes materiais. O sistema de segurança que eles utilizam, as condições de conservação das pinturas, na construção, eles lhes mantêm como se as pinturas fossem feitas ontem. É nesse sentido que nós queremos guardar nossas histórias para as pessoas. Os pesquisadores, quando eles levaram os materiais para lá, eles os guardaram por muito tempo, por diversas gerações, quarenta, cinqüenta, sessenta anos. Nós queremos fazer a mesma coisa. (Gumbula, 2003a).

Tais trocas entre os museus e os aborígenes dão lugar a dinâmicas às vezes excepcionais. Foi o caso quando, por ocasião do último festival de Garma, em agosto 2003, as duas mulheres encarregadas do banco de dados da coleção Thomson convidaram Joe Neparrnga Gumbula para uma reunião na sede, para lhe fazer uma demonstração do projeto. Neparrnga escolhe olhar as fotos arquivadas identificas pelas palavras-chave "Gupapuyngu" (seu clã) e "Crocodile Islands" (uma série de ilhas que compreende Milingimbi, seu lugar de nascença). Ele consegue identificar o pertencimento clânico de certos indivíduos nas fotos - os nomes se transmitem pela linhagem da avó maternal, e ocorre que vários Yolngu contemporâneos portam esses mesmos nomes. A última foto da série merece uma descrição detalhada. Percebe-se nela um plano de terra, delimitado pelo mar, e pode-se avistar ao longe uma outra massa de terra. Sobre o primeiro plano, pode-se ver um caçador yolngu com ar amedrontado e dotado de uma lança, pronto a atacar um $\mathrm{emu}^{6}$ que se encontra diante dele. Uma árvore totalmente ordinária completa a cena. As notas de Thomson não dão as indicações quanto à localização geográfica exata da cena. Após Neparrnga ter identificado o lugar como sendo Milingimbi, uma das representantes do museu the

${ }^{6}$ Ave casuariiforme de grande porte (atinge até $1,5 \mathrm{~m}$ de altura) e asas reduzidas (N. de T.). 
pergunta se ele conhece o nome do caçador. Neparrnga Gumbula responde "você conhece o nome do emu?" Após um silêncio, ele continua "sim, porque não existe emu em Milingimbi. Este deve ser um animal doméstico... e ele deve ter então um nome". Nós entendemos nesse momento que essa foto era uma montagem.

A interação com os antigos materiais, sejam as fotos, registros, pinturas ou sejam os objetos, deflagram fortes emoções para os Yolngu: lágrimas, risos, e podem-se observar as pessoas tocando os semblantes nas telas dos computadores. As fotos, que os Yolngu tentam recuperar dos missionários, dos antigos salariados balanda, têm um sucesso enorme: eles recobrem os muros do centro dos saberes ilustrando a história da criação do centro, e os diaporamas atraem todos os dias numerosos espectadores. A primeira empreitada lucrativa do centro dos saberes era, aliás, reproduzir as fotos já restituídas, a maioria datando dos anos 1960, para lhes imprimir, plastificar e vender às famílias de Galiwin'ku.

Neparrnga Gumbula exprime esta emoção quando diz, ao comentar uma foto histórica reencontrada nos arquivos da coleção Thomson representando seu pai, Djäwa Dhawirngu Gaykamangu, na idade de 21 anos, e outros homens do clã Gupapuyngu Daygurrgurr em torno de um rangga, um totem sagrado do clã:

Isto toca no coração das pessoas. Diretamente, as fotos vão ao interior de uma pessoa. As imagens narram pelas lágrimas, o que você olha lá agora [e mostra a foto de seu pai] é simplesmente uma foto, justo uma foto, não é mesmo? Mas as imagens vão ao interior e vão te apoiar para te tornar mais forte. O que ele [seu pai] fez, eu farei ainda mais, eu farei ainda mais. Esta foto é uma prova que me apoiará para o resto da minha vida. Porque eu olho alguma coisa, eu olho alguma coisa em um objeto sagrado. Você pode ver no retrato de Djäwa Dhawirrngu Gaykamangu a mesma coisa que você vê nesta imagem aqui [mostra o quadro representando as pinturas corporais comentadas acima], quando ele era um jovem homem. Quando ele morreu, ele mudou. Sua imagem para este mundo aqui era isto. Esta foto pode ter sido feita há uns 60 anos. Quando os Yolngu morrem, eles se transformam em qualquer coisa de mais único, de mais precioso, de um valor mais restrito, altamente sagrado. Então meu espí- 
rito se diz, quando eu olho estas imagens, que ele está morto há tanto tempo, muito tempo, mas eu, eu estou aqui e eu sou leal. Pois eu tenho sempre a cultura. E eu vou aqui acrescentar alguma coisa para tornar ainda mais preciosa esta imagem neste computador, esta tecnologia da qual nós falamos atualmente. Minha perspectiva, quando eu olho esta foto aqui, é um ângulo diferente, eu falo de um outro ângulo, uma parte diferente. Ele fala de quando ele estava lá, fotografado, e é lá que eu olho, esta geração, é qualquer coisa de muito importante para mim, não somente as fotos que eu olho agora, mas, eu olho além, é a fundação, a criação do madayin [o sacro], os rangga, os objetos sagrados, o altamente secreto e restrito. (Gumbula, 2003b).

\section{Conclusão}

Os Yolngu reconhecem o potencial que os utensílios da informática podem oferecer para manter a sua cultura e para se ocuparem de sua representação no mundo graças à Internet. A falta de competências informáticas constitui um obstáculo maior ao engajamento crítico dos diretores com o protótipo do arquivo digital, mas o centro dos saberes deve iniciar uma formação intensa no domínio, a fim de que os Yolngu possam realmente controlar o desenvolvimento do projeto.

As negociações começaram com alguns dos museus e institutos que conservam as coleções Yolngu. A AIATSIS já repatriou uma centena de manikay registrados no início dos anos 1960 por Alice Moyle, a musicóloga. Também os diretores passaram a analisar as centenas de objetos e de fotos pertencentes à coleção de Donald Thomson tiradas a partir dos anos 1940 e acervadas no Museu Victoria. Segundo eles, a identificação dos objetos que estão "dormindo" permite sua "reativação" pela reincorporação dos seus significados nas cerimônias e rituais. Esse processo criador tem o poder de tornar os Yolngu mais "fortes", pois a performance permite a reatualização das fundações ancestrais.

Um verdadeiro controle yolngu implica que o arquivo seja bem mais que um simples banco de dados interativos. A fim de fazer sentido, ele deve ser estruturado pelos princípios de organização do saber autóctone, e, mais particularmente, pela regulação do acesso aos diferentes níveis de conheci- 
mento e pelos direitos e responsabilidades que existem entre os clãs pelos laços de parentesco imutáveis, o gurrutu.

Nós vimos que existe um papel maior a desempenhar pelos antropólogos no nível da reflexão epistemológica ligada à construção de arquivos digitais. $\mathrm{O}$ trabalho de campo permite uma exploração orientada pelos modos de organização do saber para sua integração em um formato informatizado. Permite também um engajamento prático neste tipo de projeto, engajamento que pode tomar inúmeras formas: da conceitualização do sistema ao teste de protótipos com os participantes aborígenes, as relações exteriores com os museus, universidades e outras instituições relacionadas.

Os projetos de gestão do saber indígena (Indigenous Knowledge Management) tomaram novas formas depois do desenvolvimento e acessibilidade das tecnologias de comunicação da parte de numerosas populações autóctones. Em Galiwin'ku, os sistemas de classificações tradicionais se tornaram os princípios de organização de um banco de dados interativo: como na vida, identidade clânica e participação ritual regram o acesso à informação. Mas a performance da cultura através das danças, dos cantos e das atividades familiares é que permite a manutenção, a atualização e a transmissão do saber no domínio dos clãs yolngu. É deveras interessante pesquisar sobre a articulação entre a estrutura digital e a performance cultural, dado que ela permite evidenciar as maneiras criativas e criadoras pelas quais diferentes povos indígenas utilizam as possibilidades ofertadas pelas novas tecnologias para comunicar-se entre si e com os outros.

\section{Sites para consulta}

Aboriginal and Torres Strait Islander Commission. $<$ http://www.atsic.gov.au $>$. Archive Culturelle Pitjantjatjara. $<$ http://www.irititja.com>.

Buku-Larrnggay Mulka Art Centre. <http://www.yirrkala-arts.com>.

Djalu Gurruwiwi. $<$ http://www.djalu.com>.

Dousset, The Western Desert Project. <http://www.ausanthrop.com.au>.

Festival Garma (site oficial). <http://www.garma.telstra.com>.

Northern Land Council. <http://www.nlc.org.au>.

Northern Territory University Yolngu Studies. $<$ http://www.ntu.au/yolngustudies>. 
UNESCO (site do colóquio internacional Cultural Diversity. Written, Oral Expressions and New Technologies). <http://www.unesco.org/culture/ indigenous $/ \mathrm{html}$ eng/bookfair4.shtml .

Yothu Yindi Band (site oficial). <http://www.yothuyindi.com>.

Traduzido do francês por Cornelia Eckert

\section{Referências}

BERNDT, Ronald M. A Wonguri-Mandjikai Song Cycle of the Moon Bone. Oceania, Sydney, v. 19, n. 1, p. 16-50, 1948.

BERNDT, Ronald M. An Adjustment Movement in Arnhem Land. Paris: Cahiers de l'Homme, 1962.

BERNDT, Ronald M. The Wuradilagu Song Cycle of Northeastern Arnhem Land. Journal of American Folklore, Washington, v. 79, p. 195-243, 1966. BOWKER, Geoff C. Biodiversity, Datadiversity. Social Studies of Science, London, v. 30, n. 3, p. 643-683, 2000.

CHASE, Athol K. Empty Vessels and Loud Noises: Views about Aboriginality today. Social Alternatives, Brisbane, v. 2, p. 23-27, 1981.

CHRISTIE, Michael. J.; GAYKAMANGU, Waymamba; NATHAN, David (Ed.). Yolngu Languages and Culture: Gupapuyngu. Darwin: Teaching \& Learning Support Division, Northern Territory University: OLA, 2001. CD-ROM.

CHRISTIE, Michael J. Northern Territory University/Melbourne University/Yothu Yindi Foundation ARC Linkage database project. Paper presented at the Garma Music Symposium, Gulkula, 2003.

DE LARGY HEALY, Jessica; GUMBULA, Neparrnga J. Performing Ngerrk: The example of an interactive dialogue at the GIKC. Paper presented at the Garma Music Symposium, Gulkula, 2003.

GAYKAMANGU, Baltha Ng. Entrevista concedida a De Largy Healy. Galiwin'ku, Território do Norte, mai. 2003.

GUMBULA, Neparrnga J. Entrevista concedida a Jessica De Largy Healy. Galiwin'ku, Território do Norte, mai. 2003a.

GUMBULA, Neparrnga J. Entrevista concedida a Jessica De Largy Healy. Galiwin'ku, Território do Norte, jul. 2003b.

GINSBURG, Faye. Indigenous Media: Faustian Contract or Global Village? Cultural Anthropology, Washington, v. 6, n. 1, p. 94-114, 1991. 
GLICK, Leonard B. Categories and Relations in Gimi Natural Science. American Anthropologist: New Series, Washington, v. 66, n. 4, p. 273-280, 1964. GLOWCZEWSKI, Barbara. Pistes de Rêve Aborigènes: le multimédia pour la restitution d'une carte cognitive. Xoana, Paris, v. 6, p. 13-24, 1999a.

GLOWCZEWSKI, Barbara. Négociations pour la fabrication et la distribution d'un CD-ROM: Yapa, Art Rituel du Désert Central Australien. Journal des Anthropologues, Paris, v. 79, p. 81-97, 1999 b.

GLOWCZEWSKI, Barbara. Dream trackers: Yapa art and knowledge of the Australian desert $=$ Piste de reves: art et savoir des Yapa du desert australien. Paris: Unesco Publishing, 2000. 1 CD-ROM.

GLOWCZEWSKI, Barbara. Returning Research Through Multimedia and Internet. Paper presented at the AIATSIS The Power of Knowledge, The Resonance of Tradition conference. ANU, Canberra, 2001.

GURRMANAMANA, Frank; HIATT, Les; MCKENZIE, Kim. People of the Rivermouth: the Joborr texts of Frank Gurrmanamana. Canberra: National Musem of Australia and Aboriginal Studies Press, 2002. CD-ROM. KEEN, Ian. Knowledge and Secrecy in an Aboriginal Religion: Yolngu of Northeast Arnhem Land.Oxford: Oxford University Press, 1994.

KUPIAINEN, Jari. Internet, Translocalisation and Cultural Brokerage. In: KUPIAINEN, Jari; SEVÄNEN, Erkki; STOTESBURY, John A. Cultural Identities in Transition: Manifestations of Change in Local and Global Culture. New Delhi: Atlantic Publishers; Jyväskyla, Finland: University of Jyväskylä Centre for Contemporary Cultural Studies. No prelo.

LANGTON, Marcia. Cultural iconography, memory and sign: the new technologies and Indigenous Australian strategies for cultural survival. Paper presented at the International Symposium Indigenous Identities. Oral, Written Expressions and New Technologies. Paris: UNESCO, 15-18 May 2001.

LÉVI-STRAUSS, Claude. La Pensée Sauvage. Paris: Plon, 1962.

MACDOUGALL, David. Whose Story Is It? Visual Anthropology Review, Los Angeles, v. 7, n. 2, p. 2-10, 1991.

MACKNIGHT, Campbell. Macassans and Aborigines. Oceania, Sydney, v. 42, n. 4, p. 283-321, 1972.

McINTOSH, Ian. Islam and Australia's Aborigines: A Perspective from North-East Arnhem Land. The Journal of Religious History, Sydney, v. 20, n. 1, p. 53-77, 1996.

MICHAELS, Eric. Constraints on Knowledge in an Economy of Oral Information. Current Anthropology, Chicago, v. 26, n. 4, p. 505-510, Aug./ Oct. 1985.

MICHAELS, Eric. Bad Aboriginal Art: Tradition, Media and Technological Horizons. St. Leonards, NSW: Allen \& Unwin, 1994. 
MICHAELS, Eric; KELLY, Francis J. The social organisation of an Aboriginal video workplace. Australian Aboriginal Studies, Canberra, v. 1, p. 26-34, 1984.

MOLNAR, Helen; MEADOWS, Michael. Songlines to Satellites: Indigenous Communications in Australia, the South Pacific and Canada. Annandale: Pluto Press, 2001.

MORPHY, Howard. Ancestral Connections: Art and an Aboriginal System of Knowledge. Chicago: University of Chicago Press, 1991.

NATHAN, David. Plugging in Indigenous Knowledge: connections and innovations. Australian Aboriginal Studies, Canberra, v. 2, p. 39-47, 2000. POSTMAN, Neil. Amusing Ourselves to Death. New York: Elisabeth Sifton Books: Viking, 1985.

RUDDER, John. The World of the Yolngu: The People of Northeast Arnhem Land. In: THE NATIVE Born: Objects and Representations from Ramangining. Sydney: Museum of Contemporary Art, 1998. p. 113-137.

SMITH, Claire; WARD, Graeme K. Indigenous cultures in an Interconnected World. St. Leonards: Allen \& Unwin, 2000.

STENOU, K.; VACHERON, F.; GLOWCZEWSKI, B.; STANTON, J.; ROTKOWSKI, K. (Ed.). Cultural Diversity. Written, Oral Expressions and New Technologies. Paris: UNESCO. No prelo. CD-ROM.

SUTTON, Peter. Some Observations on Aboriginal Use of Filming at Cape Keerweer, 1977'. Paper presented at the Ethnographic Film Conference, Australian Institute of Aboriginal Studies, Canberra, 1978.

SUTTON, Peter. Aboriginal Country Groups and the "Community of Native Title Holders". Native Title Tribunal, 2001.

THOMSON, Donald F. Economic structure and the ceremonial exchange cycle in Arnhem Land. Melbourne: Macmillan, 1949.

TONER, Peter, G. Ideology, Influence and Innovation: The Impact of Macassan Contact on Yolngu Music. Perfect Beat, Melbourne, v. 5, n. 1, p. 22-41, 2000.

VON STURMER, John R. The different domains. In: AUSTRALIAN INSTITUTE OF ABORIGINAL STUDIES. Aborigines and Uranium. Canberra: AGPS, 1984. p. 218-237.

WARNER, Lloyd W. A Black Civilization: A Social Study of an Australian Tribe. New York: Harper and Brothers, 1937. 